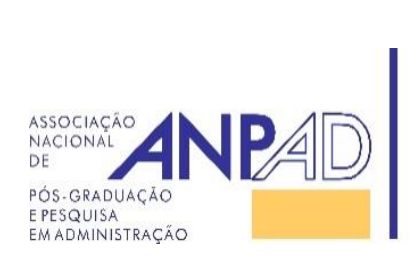

Available online at http://www.anpad.org.br/bar

BAR, Rio de Janeiro, v. 14, n. 4, art. 2, e 170048, 2017

\title{
Mind the Gap: Lessons from the UK to Brazil about the Roles of TTOs throughout Collaborative R\&D Projects
}

Elisa Thomas ${ }^{1}$ Luciana Marques Vieira ${ }^{2}$ Alsones Balestrin ${ }^{3}$

University of Stavanger ${ }^{1}$ Fundação Getulio Vargas ${ }^{2}$ Universidade do Vale do Rio dos Sinos ${ }^{3}$

Received 27 April 2017; received in revised form 4 September 2017; accepted 9 October 2017; first published online 20 November 2017.

Editor's note. Serje Schmidt served as Action Editor for this article. 


\begin{abstract}
The literature about collaboration for innovation has reported fundamental activities performed by intermediaries. In this paper, universities' technology transfer offices (TTOs) are placed as intermediaries between academic research and the industry. Our study focuses on collaborative research and development (R\&D) projects between universities and industry in order to understand the roles of TTOs throughout the whole duration of the project. The main aim of this paper is to identify the roles of TTOs throughout collaborative R\&D projects and suggest some lessons for Brazilian TTOs based on the experience of the United Kingdom. Through qualitative case studies in the United Kingdom and Brazil, the analyses show that both TTOs performed critical activities for collaborative R\&D projects. Similar activities at both TTOs were the management of partnerships in terms of negotiating contracts and the protection and licensing of intellectual property. Findings also show that the search for partners in the beginning of the project, the pacifier role of the TTO to help mutual understanding, and the active commercialisation of academic research to external partners happened only in the UK case, which may generate implications for TTOs in Brazil.
\end{abstract}

Key words: intermediary; innovation; collaborative R\&D project; technology transfer office; university-industry collaboration. 


\section{Introduction}

The open innovation concept appears in the fifth position in the ranking of core topics in technology and innovation management studies (Chesbrough, 2003; Lee \& Kang, 2017). Related to this context, literature on the National Innovation System (NIS) supports the understanding about how public policies and institutions influence the interaction among agents leading to innovation (Freeman, 1995; Lundvall, 1992). However, the lack of technical and commercial skills to attract partners creates barriers to the formation of networks for innovation (Kotabe \& Swan, 1995; Pittaway, Robertson, Munir, Denyer, \& Neely, 2004). As a consequence of the struggles regarding collaborative innovation, there has been an increasing emergence of agents who provide services for companies that seek collaboration (Chesbrough, Vanhaverbeke, \& West, 2006; Hossain, 2012). Called innovation intermediaries or brokers, they play an important set of functions within the innovation system as mediators or facilitators of cooperation (Gassmann, Daiber, \& Enkel, 2011; Gianiodis, Ellis, \& Secchi, 2010; Howells, 2006).

Universities' technology transfer offices (TTOs) are one type of intermediary promoting fundamental activities to partnerships between academia and the industry regarding innovation (Bessant \& Rush, 1995; Siegel, Veugelers, \& Wright, 2007). Recently, research on NIS is shifting from developed countries to still incipient studies located in emerging economies, also showing a recent emphasis on the role of intermediaries in the NIS (Watkins, Papaioannou, Mugwagwa, \& Kale, 2015). The interaction between science and technology is a key characteristic of the NIS (Nelson \& Rosenberg, 1993), and different NIS lead to different growth rates, being an important influence to the wealth of nations (Freeman, 2002). Therefore, the generation, transfer and commercialisation of knowledge via university-industry partnerships become pillars for the transformation of emerging economies into innovative economies (Guerrero, Urbano, \& Herrera, 2017).

Brazil shows limited cases of successful interaction between scientific and technological spheres where universities played a key role (Dahlman \& Frischtak, 1993; Mazzoleni \& Nelson, 2007; Suzigan \& Albuquerque, 2011). However, countries such as the United Kingdom (UK) and the United States developed their strong economies due to NIS where there is a notable prevalence of a scientific culture (Li \& Kozhikode, 2009; Siegel et al., 2007). Countries with good results in the generation of science and technology were able to implement, throughout history, practices for the exploitation of knowledge because of the adequate construction of their innovation systems. It explains why developing countries tend to adopt science and technology policies from developed countries (Bell \& Pavitt, 1997). In Brazil, there is a distance between production at universities and application by the private sector (Pontes, 2015) although there have been successful partnerships in some sectors (Suzigan \& Albuquerque, 2011).

Although studies of TTOs have provided valuable insights on their importance for universityindustry collaboration, Huyghe, Knockaert, Piva and Wright (2016) show that many researchers commercialise their inventions directly to the marketplace, bypassing TTOs. Yet, research on TTOs has primarily focused on describing the activity of technology commercialisation (Almeida, 2008; Etzkowitz, Mello, \& Almeida, 2005; Rapini, Chiarini, \& Bittencourt, 2015) rather than on the TTOs' help throughout an entire R\&D project. If TTO's activities are analysed in isolation, such as the commercialisation stage, we may lack the understanding of TTOs' impact on the whole project. Also, it could generate misleading implications for the practitioners who may need help in different stages of a R\&D project, not only in commercialising the results. Nevertheless, if the literature is well advanced regarding the benefits of relationships between universities and industry for innovation (Guerrero et al., 2017; Scandura, 2016) and punctual activities performed by intermediaries (Agogué, Yström, \& Le Masson, 2017; Villani, Rasmussen, \& Grimaldi, 2017), it is less advanced in outlining the role of TTOs as intermediaries throughout the entire collaborative innovation project. Therefore, the main purpose of this paper is to identify the roles of TTOs throughout collaborative R\&D projects and suggest some lessons for Brazilian TTOs based on the experience of the UK. Empirically, it presents case studies from the UK and Brazil. Although the units of analysis are inter-organizational projects and not a macroeconomic perspective, the distinguished context of the NIS in countries with different levels of development is taken into account (Carayannis, Cherepovitsyn, \& Ilinova, 2016; Munari, Rasmussen, 
Toschi, \& Villani, 2016). By analysing the role of TTOs as innovation intermediaries in similar projects in the UK and Brazil, we seek to suggest key processes for TTOs that may help the NIS of emerging countries to learn from the experience of a developed country.

The paper is organized as follows: we briefly discuss the literature on NIS to focus on TTOs as intermediaries of collaborative innovation. After the Method, the paper presents two case studies. Finally, the results raise some propositions on the role of TTOs throughout the whole duration of collaborative R\&D projects and we suggest some lessons for Brazilian TTOs based on the experience of the UK.

\section{Literature Review}

\section{NIS and university-industry relationships}

The NIS is the institutional arrangement that seeks to foster innovation in a country context (Freeman, 1995; Lundvall, 1992). From a macro perspective, the NIS aims at leveraging the socioeconomic development of countries, involving a network of public and private actors whose activities and interactions create and diffuse new technologies (Freeman, 1995).

Among the various organizations involved with the economic development of a country through innovation, universities have been playing an increasing role (Etzkowitz et al., 2005). Cooperation between universities and firms is reported at the NIS literature as key for knowledge creation and therefore for innovation (Rapini et al., 2015). The so-called entrepreneurial university incorporates economic development as a university mission complementing their traditional contributions of research and teaching (Trippl, Sinozic, \& Smith, 2015).

Within this context, universities provide fertile knowledge-intensive environments to support the exploration and exploitation of innovation "especially in emerging economies, where governments have created subsidies to promote enterprise innovation through compulsory university partnerships as a strategy to stimulate regional economic development" (Guerrero et al., 2017, p. 3). However, Radosevic (2011) points out that there is a failure within the relationship between science and technology in the context of catching up and laggard economies due to the application of conventional policy "based on the logic of the linear innovation model while the reality of these countries is based on the logic of the interactive innovation model" (p. 374). He argues that "the interactive model focuses on the social process underlying economically oriented technical novelty and design (engineering)" (Radosevic, 2011, p. 374) instead of policy focused on R\&D budget. Kim and Lee (2015) add that different impacts of scientific knowledge on economic growth depend "upon the effectiveness of the national innovation system, in particular the degree of effective commercialisation of scientific knowledge, which is lacking in latecomer economies" (p. 44).

\section{TTOs as intermediaries of collaborative $R \& D$ projects: a review and context}

Some institutions such as TTOs influence the formation of relationships by acting as intermediaries in the search for partners and therefore in the establishment of inter-organizational network for innovation (Battistella, De Toni, \& Pillon, 2016; Gassmann et al., 2011). Using the review by Howells (2006), we define innovation intermediaries as proactive service organizations within innovation systems that have close and continuous interactions with its clients, which involve varied and crucial functions in supporting innovation. Intermediaries or brokers (Chesbrough et al., 2006; Hossain, 2012) can help the formation of relationships that require complementary knowledge, resource sharing and coordination amongst organizations involved in collaborative R\&D projects. The intermediary is located between the seeker of knowledge and resources needed for innovation on one side, and the source of them on the other side (Gianiodis et al., 2010). Or as the distinction by Meulen and Rip (1998), an intermediary is in between the top level of government agencies and the research 
performance level. Billington and Davidson (2013) state that the use of intermediaries may extend the boundaries of partner search, because larger networks turn into higher returns on innovation investment. Siegel, Veugelers and Wright (2007) say that TTOs are intermediaries between suppliers of innovations (university scientists) and organizations that can potentially (help to) commercialise them. Such intermediaries may be university liaison departments, research councils, funding agencies or private companies. Different organizations can benefit from the services provided by an intermediary. According to Winch and Courtney (2007), universities use brokers to seek partners for their externally funded research programs while firms use brokers to shape research programs to meet the perceived needs of the industry.

Natalicchio, Petruzzelli and Garavelli (2014) stated that the use of intermediaries is consistent with the increasing tendency to decompose the whole innovation process into distinct phases. Agogué, Yström and Le Masson (2013) say that beyond brokering and networking, intermediaries may also take an active role in joint exploration and creation of knowledge.

To face the challenge of finding partners with common goals, the intermediary scans the environment and selects the players, establishing the procedures and tasks for a possible partnership as network orchestration (Agogué et al., 2017; Batterink, Wubben, Klerkx, \& Omta, 2010). In addition, the intermediary may be responsible for typical issues of innovation management in an interorganizational context, such as conflict management and prevention of opportunistic behaviour (Hacievliyagil, Maisonneuve, Auger, \& Hartmann, 2007). The governance can ensure that the actors engage in collective and mutually supportive action and that conflict is addressed (Provan \& Kenis, 2008). This role performed by the intermediary may be essential because innovation network fails due to inter-firm conflict, displacement, lack of scale, external disruption and lack of infrastructure (Pittaway et al., 2004). Some of these reasons could be minimized or even eliminated from the right governance of the network and its activities.

Batterink, Wubben, Klerkx and Omta (2010) found that the role of intermediaries is relevant in $R \& D$ project management, especially in networks with small and medium enterprises (SMEs) in food agriculture. SMEs do not have the experience and knowledge to encompass all the necessary details for the preparation of contracts. The authors explain that "in contrast to the SMEs, innovation brokers have ample experience with earlier innovation projects and often have explicit ideas and even templates for setting up appropriate coordination mechanisms, such as contracts" (Batterink et al., 2010, p. 60). Therefore, the TTO can assume a strategic role when dealing with collective projects involving SMEs.

One specific issue of $R \& D$ projects is the distribution of results which have arisen from the relationship. The intermediary may influence the definition in relation to intellectual property and technology transfer as results of R\&D activities. Howells (2006) states that the issue of protecting the results of $R \& D$ is growing for intermediaries. They can provide independent advice and mentoring on protecting intellectual property and evaluation on the outcomes of R\&D collaboration. At the same time, Dodgson, Gann and Salter (2006) argue that the issue of intellectual property is not well resolved in joint $R \& D$ projects. According to them, it is not entirely clear how it will be managed, although the use of intermediaries helps in this matter.

Benassi and Di Minin (2009) argue that the main objects of transactions in technology markets are patents and licenses, as they generate direct revenue. The role of patent brokers is to promote the negotiation offering an acceptable option to both organizations. Manufacturing firms may reduce their transaction costs in technology markets by collaborating with intermediaries such as TTOs (Lichtenthaler, 2013). Then Billington and Davidson (2013) post that one of the key roles of intermediaries, apart from the linking seekers to solvers, is related to the distribution of finances involved in the transfer of technology. Their approach is focused on technology transfer transaction, on outsourcing R\&D services, and on negotiating intellectual property.

This section presented previous literature to support the discussion on TTOs as intermediaries strategically acting in taking innovation to the marketplace, not only by transferring technology, but also by fostering innovation through other key activities. 


\section{Method}

The research uses descriptive multiple case studies (Eisenhardt, 1989; Yin, 2009), chosen because they "emphasize the rich, real-world context in which the phenomena occur" (Eisenhardt \& Graebner, 2007 , p. 25). We took an inductive approach to structure the interviews and analyse the responses using previous literature as ground. It means that although we had a guide provided by previous literature, we also looked for new dimensions emerging from the fieldwork data collection (Van de Ven, 2007).

For the selection of cases, we adopted the principle of theoretical (not random or stratified) sampling, where "cases are selected because they are particularly suitable for illuminating and extending relationships and logic among constructs" (Eisenhardt \& Graebner, 2007, p. 27). Our first selection criterion for the case studies was that the TTO acted in collaborative innovation projects - defined as formalized interactions for the co-production and transfer of knowledge specifically for advancing new technologies (Santoro, 2000) -, not only on business transactions of technology. Secondly, the TTO must be an active agent and not just a channel or means through which organizations could meet. The R\&D project was agreed upon by each TTO's representative to meet the research objectives. From the range of partnerships in each TTO's portfolio, we chose projects that received more help from the TTO and that the TTO was involved throughout the entire project.

The empirical research collected data from TTOs in the United Kingdom and Brazil. The criterion selection was to search cases from distinguished NIS to provide insights, especially from a developed country's experience, to an emerging context such as Brazil. The British case presents the StarStream project by the University of Southampton in collaboration with partners from the industry. The technology adds ultrasound and bubbles to a low volume stream of water. At the time of the research, the development was in progress in a number of areas related to surface cleaning including nuclear decontamination. The intermediary was the Research and Innovation Services (R\&IS) department. The external partners in this $R \& D$ project were varied: a small technology company managed by its founder; a large multinational company producing consumer goods and a large government nuclear company, to give some examples. The University of Southampton is ranked among the top one percent of global universities (QS, 2017) being one of the leading entrepreneurial universities in the UK. The University works with over 1,000 external organizations and over 40 percent of research projects involve one or more business partners. The portfolio of rolling patents includes more than 300 active patent families with an annual income of about $£ 1 \mathrm{~m}$ (University of Southampton, n.d.).

The Brazilian case presents the R\&D project called Force for Elastomers, performed at the Chemistry School of the Federal University of Rio Grande do Sul (Universidade Federal do Rio Grande do Sul [UFRGS]) in Brazil, with the intermediation of the Secretary for Technological Development (Secretaria de Desenvolvimento Tecnológico [Sedetec]), responsible for the liaison between academia and industry. Force for Elastomers case was chosen for being the only local partnership at the moment of data collection. The project had the cooperation of the firm Frenzel, a producer and exporter of rubber parts for automotive, electronics, agriculture, energy, construction, machinery, oil and gas industries. UFRGS was ranked the fifth top university regarding innovation in Brazil (Folha de S. Paulo, n.d.). The University had 164 patents filed in Brazil and 24 patents filed abroad from 2007 to 2012.

\section{Data collection}

The data collection comprised three sources of evidence: semi-structured in-depth interviews, observations, and secondary data as documents and videos in both case studies. The combination of multiple eliciting data aimed at improving the research validity.

Guidelines for interviews were developed based on prior literature on the subject and were used in both cases. Interviews were audio-recorded to allow more than one listening and consultation. The interviewees were staff from the universities and from external partners of the projects, as detailed at Table 1. 
Table 1

\section{Respondents from Case Studies}

\begin{tabular}{|c|c|c|}
\hline Respondent & Abbreviation & Details of interviews \\
\hline $\begin{array}{l}\text { Researcher from the research group that launched } \\
\text { StarStream technology at University of Southampton. }\end{array}$ & $\mathrm{R} 1$ & Meeting on $10 / 07 / 2013$. \\
\hline $\begin{array}{l}\text { Collaboration Manager for the Faculties of } \\
\text { Humanities; Business and Law; and Social and } \\
\text { Human Sciences at R\&IS. }\end{array}$ & $\mathrm{R} 2$ & Meeting on $17 / 01 / 2013$. E-mails. \\
\hline $\begin{array}{l}\text { Collaboration Manager for the Faculty of Physical and } \\
\text { Applied Sciences at R\&IS. }\end{array}$ & R3 & Meeting on 15/05/2013. E-mail. \\
\hline $\begin{array}{l}\text { Collaboration Manager for the Southampton Marine } \\
\text { and Maritime Institute at R\&IS. }\end{array}$ & R4 & Meeting on $15 / 05 / 2013$ \\
\hline $\begin{array}{l}\text { Collaboration Manager for the Faculty of Natural and } \\
\text { Environmental Sciences \& Institute for Life Sciences } \\
\text { at R\&IS. }\end{array}$ & R5 & $\begin{array}{l}\text { Meetings on } 01 / 05 / 2013,17 / 05 / 2013 \\
\text { and 30/07/2013. E-mails. }\end{array}$ \\
\hline $\begin{array}{l}\text { Technical Specialist from the Decontamination } \\
\text { Centre of Expertise at Sellafield Ltd. }\end{array}$ & R6 & By telephone on $17 / 07 / 2013$. \\
\hline Senior Business Development Manager of Philips. & R7 & Via skype on $06 / 08 / 2013$. \\
\hline Former Project Leader of Philips. & $\mathrm{R} 8$ & Via skype on $16 / 08 / 2013$. \\
\hline Founder and current director of Ultrawave. & R9 & Meeting on 10/09/2013. E-mail. \\
\hline Technological Development Assessor of Sedetec. & $\mathrm{R} 10$ & Via skype on 09/09/2013. E-mails. \\
\hline Legal Assessor of Sedetec. & R11 & $\begin{array}{l}\text { Meetings on } 21 / 10 / 2013 \text { and } \\
04 / 12 / 2013 \text {. E-mails. }\end{array}$ \\
\hline Professor and researcher at UFRGS. & $\mathrm{R} 12$ & Meeting on 01/11/2013. E-mails. \\
\hline Intellectual Property Coordinator at Sedetec. & $\mathrm{R} 13$ & Meeting on $04 / 12 / 2013$ \\
\hline Founder and current director of Frenzel. & $\mathrm{R} 14$ & Meeting on $21 / 11 / 2013$. \\
\hline Industrial Manager of Frenzel and student at UFRGS. & $\mathrm{R} 15$ & Meeting on 21/11/2013. E-mails. \\
\hline
\end{tabular}

Another technique for collecting data was direct observation. According to Yin (2009), direct observation is useful in providing additional information and understanding of the case. There is an implicit limitation though, because the presence of the observer may affect the behaviours of observed interviewees. Such limitation for the result of the research is minimized here by the use of other sources of data collection. At the UK case, the observations took place at R\&IS department concerning relationships among members of the staff, i.e. between faculty-focused teams with thematic-focused teams, and between the Director and the Head of Faculty Support with collaboration managers from different faculties. Also direct communications among external partners and faculties' researchers were observed. At the Brazilian case, observations were made at the department at the university regarding meetings of members of the staff, and direct communication among external partners and the university's research group.

The documentation analysis was used to corroborate and augment evidences from other sources of information, as suggested by Yin (2009). The limitation on using external documents as evidence is that they are written for a specific audience and purpose. Such limitation is diminished by the triangulation with other sources of data. For us, the documents allowed some inferences about the cases. At the UK case, the documents used were: the handbook explaining modes of collaboration handed for external organizations; the document called Principal Services provide by R\&IS, specifying the department's responsibilities; news about innovation partnerships at the university's website; the partners' websites; the Invention Information Form where researchers and research groups report a 
potential idea for commercialisation; and the Confidentiality Agreement for partnerships. At the Brazilian case, some documents used as sources of data were: the handbook explaining modes of partnerships and the departments of the university that need to be involved for the approval; the Request for the Search on Patent Databases form, where the research group describes the invention and suggests keywords for the filing process; the Invention Report used to begin the patent process, where the research group fills information about the activities that led to the discovery; a video from a research competition presented by the undergraduate student involved in the second phase of the project; Sedetec's organization chart; the cover of the collaborative contract's addendum where there was the list of departments within the university through which the addendum had passed for signatures; and three documents from the University's Council (Conselho Universitário [CONSUN]).

\section{Data analysis}

After the data collection, a detailed within-case description was developed about each R\&D project, drawing from the interviews, observations and collected documents. Our focus was on activities performed by the TTO in each R\&D project, considering the Oslo Manual's definition of innovation activities as "all scientific, technological, organisational, financial and commercial steps which actually lead, or are intended to lead, to the implementation of innovations" (Organisation for Economic Cooperation and Development [OECD], 2005, p. 18). The material was organized to present the temporal linkage of events of each R\&D project. Some interviewees' speeches were reproduced to illustrate their opinions on the situations. After individual cases' description, the content analysis technique (Bardin, 1991) was used for a comprehensive understanding about TTOs throughout collaborative R\&D projects. It aimed at identifying patterns of practices to answer the main research objectives and best practices considering results of the projects. As a qualitative research, the cross-case analysis tried to reach a more in-depth understanding of the phenomenon. As oriented by Creswell (2013), the data analysis for research following a qualitative approach should inductively build from particulars to general themes. In order to do it, empirical evidences were matched and related to previous theoretical literature to give rise to research propositions inductively developed. Synthesizing the research findings, the whole R\&D project according to the TTO's help was represented on a processual framework. As a conclusion, we draw some implications and lessons for Brazilian TTOs from the UK experience.

\section{Limitations, reliability and validity of the study}

Some limitations associated to the methodological option must be acknowledged. We focus on the roles of TTOs in one project at each university, not analysing other projects. Instead, analysing the whole portfolio of collaborative projects per university could have shed lights on differences between occasional and recurrent TTOs' activities, both in terms of the activity itself and its impact. However, due to constant feedback from the TTOs' representatives and having a draft of the paper reviewed by key informants in Brazil and in the UK, we could assure that the chosen projects reflect TTOs main roles. Construct validity deals with the establishment of correct operational measures for the concepts being studied. There are three tactics suggested by Yin (2009) to increase construct validity: using multiple sources of evidence; establishing a chain of evidence; and having the draft reviewed by key informants. All of them were followed to reduce any bias or misinterpretation of the case studies.

The internal validity, as explained by Yin (2009) should be a concern for explanatory or causal studies. It is also a concern extended from the broader problem of making inferences. Regarding that, Yin (2009) and Riege (2003) suggest within-case analysis, then cross-pattern matching, explanationbuilding and time-series analysis as techniques in case studies to achieve internal validity. According to Yin $(2009$, p. 141) "the better case studies are the ones in which the explanations have reflected some theoretically significant propositions" and "the social science propositions, if correct, can lead to major contributions to theory building". So at the present research, the internal validity was handled by developing within-case analysis of each collaborative R\&D project considering the timeline of events, before the multi-case analysis that searched for patterns of practices. When analysing multiple-case studies, the goal was to build an overall explanation that suits each individual case, even though the cases vary in their details. The external validity deals with the degree to which a study's findings may 
be generalized across social settings. Here, the external validity was increased by studying two different R\&D projects and by analysing the practices of TTOs from different countries.

The fourth test is reliability. According to Bryman (2001) there is an external and an internal reliability. External reliability is the degree to which a study can be replicated. He explains that this is a difficult criterion to meet in qualitative research since it would be impossible to freeze social setting and the circumstances of the initial study. The internal reliability is the consistency of data collection, analysis and interpretation. It is the degree to which different observers would get the same result from the study (Yin, 2009). As suggested by both authors, reliability was addressed here by developing the protocol for interviews and following the same standards for data gathering and analysis in all cases.

\section{Results}

\section{StarStream project - University of Southampton}

In 2006, two Professors, one from the Institute of Sound and Vibration Research and one from Chemistry, launched a research project of an ultrasonic cleaning technology. At its start, the research received university support from the Engineering and Physical Sciences Research Council from 1999 until 2006. It was from 2006 on that external partners began to be involved. When the researchers informed the Research \& Innovation Services (R\&IS) department that they had an invention, the department hired an external patent attorney to deal with the requirements for the application. The collaboration manager $(\mathrm{CM})$ of the project commented that it is very important for the attorneys to spend time with the scientists, to hear first-hand about the technology and receive demonstrations. The patent application was filed in September 2009.

Until the end of the data collection, three CMs from R\&IS department have worked on this case: the first one was involved for more than two years; the second CM helped the academics for around six months; and the third CM had been working on the project since 2011. The academic researcher confirmed the importance of R\&IS on the project, saying that the CMs gave a lot of support in terms of their time and expertise to interact with companies. According to him:

The best advice is dealing with the companies, managing their expectations and making sure that we understand the companies' motivations, processes and needs. Managing companies is quite difficult because we would like to talk about the science. However, most of companies' meetings focus on getting results rather than understanding which can enable results. This is a subtle but important difference. We also do not know how much things are really worth financially speaking. (R1)

According to the academic, R\&IS' staff identify which companies have resources and capability to commercialise the technology. As a CM comments:

Our biggest role is to facilitate the interaction between two cultures that have very different drivers. Academics are driven by publications and research; and industry is incentivized by delivering shareholder value. Then we have to interpret all the human factors and behaviours that surround these drivers, and try to interpret if a company is going to be a good partner in taking a technology to market and whether the academics can work well with them. (R5)

The first organization to which the technology was disclosed was a venture capital company that commercialises intellectual property primarily from its research partner. However, due to the uncertainty of the technology, the organization decided not to invest in a spin-out company at that moment. After that, from late 2009 into Spring 2010, the CM was actively looking at market sectors and opportunities for partnerships. He had discussions and visits from an international company that produces medical devices. The company was interested in cleaning contaminated appliances, but they did not establish a partnership. 
At the same time, he got in contact with a UK technology company specialized in consumer electronics that invested financial resources in the development. Through EPSRC (Engineering and Physical Sciences Research Council) funding, which is a knowledge transfer secondment, a PhD student interacted with the company in terms of testing the technology at the university's laboratory, and going to the firm's facilities to test it with different materials. At that time, it was difficult to turn the technology into a prototype for a product as the company wanted. Therefore, the CM started searching for other partnerships. In his words, "I wanted to get feedback from the technology by demonstrating it. Every different way we tried to demonstrate to a new potential user, we actually had to go back to the laboratory and conduct further tests and subsequent development. The technology is a very sensitive phenomenon" (R3).

In 2011, the research was awarded the Royal Society Brian Mercer Award for Innovation. The Award is also associated with interacting with firms. One of the partners from the industrial side was a company from Cardiff, a specialist supplier of ultrasonic cleaning equipment. At the time of the interview, the University and the company still did not have a signed licensing agreement. The partners were collaborating based on trust for a future reward. The publicity that came after the Brian Mercer Award brought interest from external firms. The academic-researcher said that "some of them have been useful, others were not related to our technology. R\&IS staff was very helpful in identifying that difference" (R1).

Another partnership that started around the same time was with Philips, regarding consumer applications. The company, headquartered in the Netherlands, has a department in the UK that looks at new ideas coming out of universities. This relationship started at another department, with a professor from Mechanical Engineering who had been collaborating with Philips for many years. On a R\&IS meeting, the CMs had the idea of offering StarStream technology to the company. The Senior Business Development Manager at Philips, involved in the negotiation, said that R\&IS staff helped in defining the rules of the contract, as the area in which the company would get exclusivity, the payment and patent rights. The Project Leader affirmed that R\&IS' collaboration manager played a major role in bridging the relationship between the academics and the company. He explains that:

the professors tend to think that their technology is basically done and can be brought to market soon,
however the companies see most of the technologies as not practical to become a product that anybody
would buy. We were asking questions about safety, environmental issues, costs and practicality to the
professors. So it was quite useful to have the CM at the meetings, helping us. He tried to translate our
communications. (R8)

The company has funded the development of a prototype built by the academics in a three months project. In addition, the company spent time on testing it. Another partner investing on the technology was the British company Sellafield Ltd, which has funded the development of prototypes (University of Southampton, 2013). The research group was actively collaborating with the Technical Specialist from the Decontamination Centre of Expertise of the firm in building prototypes for different cleanings. The first contact between the company and the university came from an approach of the CM. The information was sent to the commercial group at Sellafield Ltd. After that, the company's Technical Specialist visited the university, where he met the CM and the research group. Legal issues were sorted out and they signed the contract. The chemist says that R\&IS helped defining the commercial value of the technology to the firm and helped establishing conditions for licensing the use of the technology in the future. $\mathrm{He}$ adds that "CMs have only an appreciation of technical issues but they are keen of sorting out legal assessment. And they are flexible with arrangements" (R6).

Another negotiation began with a glass manufacturer. The company has funded the development of a prototype, and the academics sent some samples for testing. However, the cleaning was not doing as expected, and the organizations (university and company) stopped the relationship.

After finishing the interviews for this study, the academics were working on bespoke industrial projects. The massive domestic market was put to a second level of importance, and the technology was been worked more on an industrial-base. The academic-researcher commented about the whole project: 
It has been a very interesting experience. I come from a scientific background rather than a business exploitation or patent licensing. Having somebody from R\&IS is very good in terms of smoothing these issues and handling things that we do not have expertise in. (R1)

As it may be seen from the information above, collaborations with different companies had taken place since the beginning of the research on the new technology. Some periods had more than one partner on unrelated industries.

\section{Force for elastomers}

An undergraduate student of Industrial Chemistry (R15) had an idea for her final assignment during classes with her professor in 2010. The student was the Industrial Manager at the company founded by her mother. In the first term of 2011, the professor supervised the student's research that led to a discovery.

After having researched the new technology and reached a positive result of tests, the professor says that it was not easy to apply for the patent:

We were dealing with a small company that does not have the expertise of registering intellectual property. In previous projects, we had the support of big companies with history in patenting. Now I got involved in finding the ways and understanding the steps to file the patent. But I am an academic without experience in this matter. (R12)

From this moment on, the Secretary for Technological Development (Sedetec) got involved in the collaborative project. Firstly, the Intellectual Property Coordinator (R13) helped with the search of existing patents on international databases to check if the technology or something similar was already registered. The professor says that the research group knew that nothing had been published in scientific journals, but they were not sure about patents because this is something they do not deal with on a regular basis.

Sedetec had an important role at this point because the professor, as an academic, did not have knowledge about the patenting process; and the company had limited resources to help in this situation. The second activity performed by Sedetec was writing the patent application form. The department hired an external attorney for it. The TTO helped with the attendance to regulations for the Patent Office, for example deadlines and details on the co-ownership inserted in the form. The Intellectual Property Coordinator said that they have had experience in the same area before, related to the School of Chemistry, because the professor had already filed another patent. Sedetec also helped financially the patenting process.

After having patented the invention, the technology was licensed to the firm. According to the Professor, the engagement of Sedetec in the negotiation of licensing is fundamental for many reasons. One is that the academics do not know the value of the technology and the protocols for the business. The second benefit of the involvement of Sedetec is that academics do not know how to negotiate; they do not possess commercial skills. Moreover, in the third place, the Professor affirms that Sedetec's engagement in the negotiation keeps a healthy research environment between the research group and the external partner.

The firm produced the technology during around a year and a half. Its client was from the automotive industry, but it was not a new client to the firm. The negotiation with the client for the use of the new technology was carried out by the firm without the involvement of Sedetec. The founder and director of the company said that the firm did not try hard to negotiate the technology because the firm does not have the structure for it. Even so, there was another company in Brazil interested in the application of the new technology. The director of the firm mentioned that Sedetec does not help in the commercialisation of the new technology, although the university is the co-owner of the patent. She complained that "there is no structure to negotiate the technology. We have to do it ourselves" (R14). 
After the patenting process and use of the technology, the firm and the university formalized another collaborative project to keep researching the same subject. Sedetec helped in identifying which interaction model would be applied to the case before developing the partnership contract. As there is an interaction with a firm, there are many rules that must be satisfied. Each project starts being developed by the research group within its school at the university. Afterwards Sedetec acts as a filter to check if all details are correct to allow the partnership for the research.

Sedetec approved an internship grant so that the research group could hire an undergraduate student, because all technological scholarships pass through the TTO. When data was collected for this paper, there was an undergraduate student as an intern and a post-doctoral researcher dedicated to the project apart from the involvement of the professors and of the firm.

\section{Discussion}

Empirical data showed different roles by the TTOs in the two case studies. While the TTO in Brazil mainly deals with paperwork and IP, it assumes a strategic role in the UK. Based on the main processes performed by TTOs in the case studies and supported by previous literature, this study raises some propositions. A first aspect to point out is the search of possible partners performed strongly as assessed by the TTO in the British case, albeit different from the Brazilian case. At StarStream project, the TTO searched for external partners with whom the academic group did not have contact. Throughout the project, R\&IS' efforts resulted in contracts with four external partners. At the Brazilian case, the TTO did not need to search for a partner because the partners knew one another and identified the possibility to work together before contacting Sedetec. The first case follows what Batterink et al. (2010) name as network composition, which would be the function of an intermediary when it scans and selects strategic and complementary partners. However, the Brazilian case distinguishes from previous works about intermediaries' activities in searching for partners, such as Winch and Courtney (2007) and Alexander and Martin (2013) who state that for academics and companies to engage directly without using their respective TTOs is now the exception, not the norm.

Another point of attention that emerges from the case studies is that the intermediary needs to understand about the technology and its client to be able to search for external partners. The British project had different representatives from the TTO at different times. Although new people may bring new knowledge and contacts, there may be a loss of trust in relationships previously established. At the British project, there were different ways to solve this situation: the TTO carries out frequent meetings among the collaboration managers, and the department keeps an online registration of everything that happens with projects, companies and academics. These initiatives confirm the findings by Agrawal (2006) who says that focusing on the role of specialized innovation intermediaries is not enough to enhance technology transfer. He affirms that it is better to engage the inventor in an active collaboration with technology transfer experts.

Based on the findings and supported by literature, the search and selection of partners as one of the main activities of TTOs as intermediaries in joint $R \& D$ projects leads to the development of the following proposition:

Proposition 1: The intermediary helps with the identification and selection of possible partners for collaborative $\mathrm{R} \& \mathrm{D}$ projects.

During the execution of the collaborative projects, the two cases showed the involvement of TTOs from both universities in terms of access to resources. At the British case, the TTO was directly responsible for the financial resources either from the university or from external partners. At the Brazilian case, the TTO helped with financial resources to allow human resources for the research, although the TTO did not get involved directly in hiring staff. Financial funding is a fundamental resource for R\&D (Okamuro, 2007); and the help of TTO regarding financial resources was a very 
important issue for the existence of the British project. Financial mobilization by intermediaries may help $\mathrm{R} \& \mathrm{D}$ projects to leverage public and private funds more effectively (Polzin, Flotow, \& Klerkx, 2016).

However, other sources (Department for Business, Innovation \& Skills [BIS], 2012; Instituto Brasileiro de Geografia e Estatística [IBGE], 2013) rank human resources as fundamental for R\&D; and the findings showed that the British TTO did not get involved with this issue. The Brazilian case shows the confluence with the findings by Alexander and Martin (2013), who assume that intermediaries in the interface of universities and firms should establish knowledge-based boundary-spanning activities through the effective mobilization of people (human resources). And the help of Sedetec in approving a scholarship for an undergraduate student fits in this situation. Hence, we formulate:

Proposition 2: The intermediary facilitates access to necessary resources for collaborative R\&D projects.

Another important assistance performed by both TTOs concerned the establishment of contracts to rule partnerships with external parties in order to hinder opportunistic behaviour from partners. The previous experience of the TTO added to some pre-established contracts and modes of partnerships was an important help to the participants of the projects in the United Kingdom and in Brazil. The TTOs (R\&IS and Sedetec) were not responsible for writing all the contracts by themselves; the academics were usually involved. Provan and Kenis (2008) state that governance may ensure that actors engage in collective and mutually supportive action, and that conflict of interest between partners is addressed. Also, the previous experience of TTOs with other $\mathrm{R} \& \mathrm{D}$ projects and templates for establishing appropriate coordination mechanisms matches with Batterink et al. (2010) when they say that the intermediary uses lessons learned from past projects. That role agrees with Alexander and Martin (2013) who affirm that the intermediary helps the identification of the type of research projects, the collation of costs, the control of key phases of negotiation, the authorisation of, and follow-up on progress of each contract.

Formal contracts are used as governance mechanisms, but Bachmann and Zaheer (2008) add trust, reciprocity and fairness of the relationship as informal methods of coordinating collaborative initiative. The two studied cases had activities based on trust. At the British case, the TTO revealed the technology developed by the academics to partners sometimes without a signed contract. For example, the company Ultrawave was testing the technology at its factory, and presenting it to its clients for two years before signing a formal contract with the University of Southampton. The only official partnership involving the two organizations was Ultrawave's support for the Royal Society Brian Mercer Award. This situation was the same in the beginning of the Brazilian case, Force for Elastomers, when the student was developing her research for the final paper for graduation. The contract was signed between the parties (company and university) after the research had already started. One could relate the practices based on trust described by Dyer and Nobeoka (2000), where certain knowledge is shared with partners as if there was no owner. Trust plays a positive role in mitigating transactional problems of uncertainty (Jensen, Palangkaraya, \& Webster, 2015).

The involvement of the TTO throughout R\&D activities was seen only at the British case, where the collaboration managers from R\&IS department were in constant contact with the academics and their external partners. As mentioned by Batterink et al. (2010), the stimulation of network interactions would be typical in the inter-organizational context. Klerkx, Hall and Leeuwis (2009) also say that an intermediary has an important role between the two worlds of industry and research, because they have different mindsets, expectations and time frames. In this regard, innovation intermediaries may act as translators by facilitating a situation that enhances knowledge transfer during the project improving the cognitive proximity of partners (Villani et al., 2017). At the British case, the Project Leader of Philips declared that the TTO helped him to understand information coming from the professors and the other way round, translating practical needs of the company to academic terms. Related to that, Kivimaa (2014) endorses the importance of developing a shared understanding among the partners to facilitate knowledge transfer, and the intermediary acts as an impartial contact point or voice for new networks of actors. In Brazil, legal regulations state that there should always be a foundation to manage procedures 
and finances of partnership contracts between university and industry for R\&D. Still, in our case study, the Brazilian TTO does not remain involved with partners throughout the project. Based on the data, analysis, and foregoing discussion, we conclude with the following proposition:

Proposition 3: The intermediary helps coordinate activities among partners throughout collaborative $R \& D$ projects.

At the end of joint R\&D projects, the two cases showed the involvement of TTOs on the definition and distribution of the results of the project, mainly in the protection of the novelty and, in the UK case, a role in the commercialisation of the innovation.

At the Brazilian case, the TTO was responsible for registering the patents and helping with its costs, but the department does not commercialise technologies created at the university. Even so, the academic commented that the engagement of Sedetec in the negotiation of licensing is fundamental, when there is a firm interested in a business deal with the university. Not all collaborative R\&D projects end up in licensing the technology for the external partner. This situation follows what Dodgson et al. (2006) relate about the issue of intellectual property not being well resolved in joint R\&D projects. Also Deschamps, Macedo and Eve-Levesque (2013, p. 33) state that "even the intermediaries, whose role is to guide SMEs in university-enterprise collaborations, suffer themselves from the lack of appropriate IP transfer and sharing tools, and do not perceive the need to offer better support in this regard".

At the University of Southampton, the situation was very different from the Brazilian case because the TTO was responsible for negotiating financial investments from external partners. The department is responsible for market researches and is aware of the value of the inventions at an international level. Therefore, the staff is able to offer technologies to external organizations identified as possible partners. The department is responsible as well for filing patents and other types of protecting the inventions. This role agrees with Benassi and Di Minin (2009) who say that, under specific circumstances, the transaction would not occur or would be much more difficult if an intermediary were not present. However, different from the results here, these authors emphasize the role of universities in Latin America that, according to them, have taken up the new challenge of transforming incentive structures and patenting research results. This leads us to posit:

Proposition 4: The intermediary influences the protection of the intellectual property and commercialisation of results of collaborative $R \& D$ project.

Still regarding the final stage of the project, another important role of the TTO concerns the decision about the achievements of R\&D activities performed by the partners. It means that the TTO influences the decision about the flow of the project according to different results of R\&D activities. If the R\&D activities do not reach the expected result, the TTO may return to the initial stages of partner search and access to resources, when the collaborative project will keep being performed.

The theoretical and conceptual issues previously addressed allowed a better understanding about the main activities and help of TTOs throughout an entire inter-organizational innovation project. Based on literature, this study's propositions and empirical evidence, we propose a framework of key processes performed by TTOs in collaborative R\&D projects (Figure 1). 


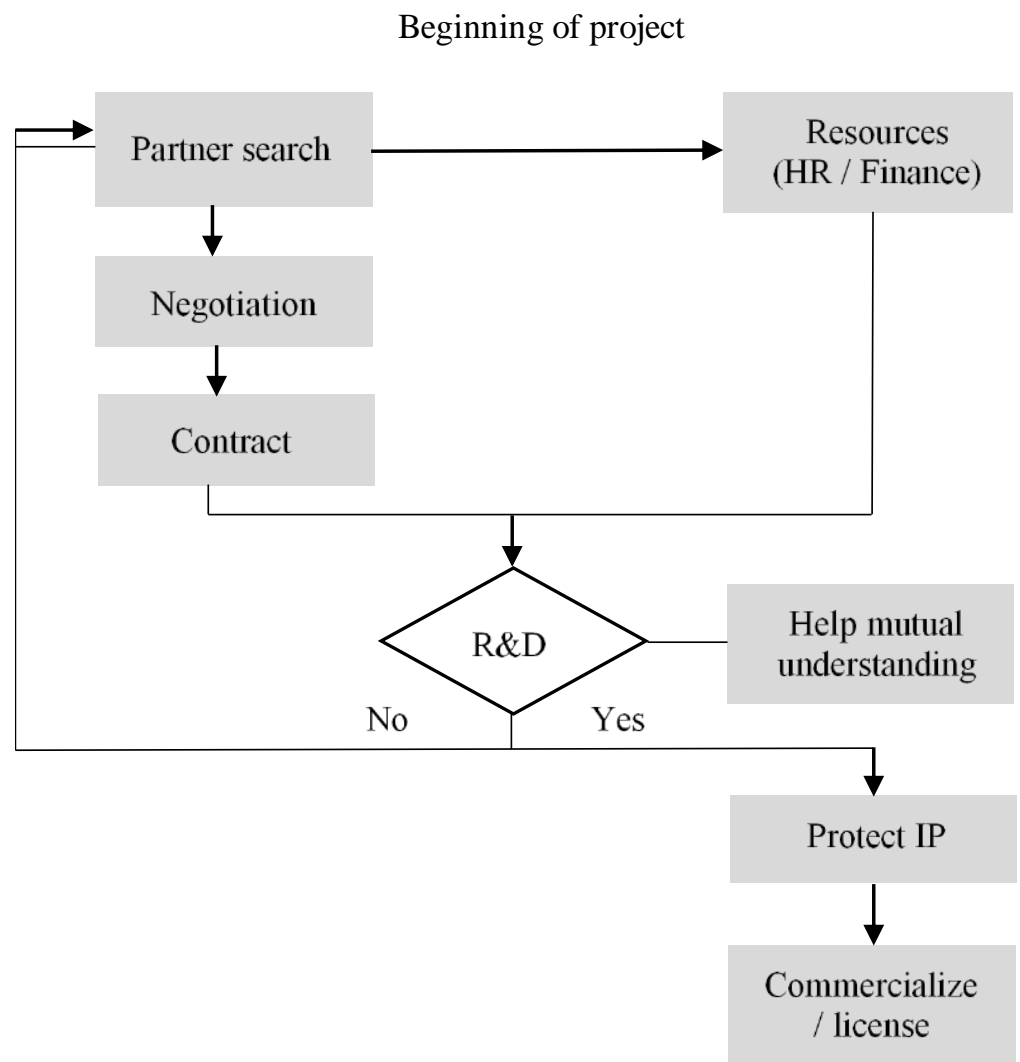

Figure 1. Main Activities Performed by TTOs' throughout Collaborative R\&D Project

At Figure 1, the main activities performed by TTOs in university-industry collaborative projects are highlighted in grey boxes. They refer to: (a) the search for partners; (b) the negotiation for the terms of the partnership; (c) the writing of contracts for partnerships; (d) the access to financial and human resources as fundamental elements of planning a collaborative R\&D project; (e) the translator or pacifier role to help partners to understand one another; (f) the protection of the intellectual property when R\&D activities have a positive result; and $(\mathrm{g})$ the commercialisation of technology or the licensing of intellectual property in the end of the project. When R\&D have not yet reached the expected result, the intermediary helps in obtaining more resources and searching for new partners. Although in the Brazilian case study the TTO played a restricted role mainly in paperwork/bureaucratic activities, from the literature and the UK case study it is clear that TTO can help collaborative R\&D projects in a more entrepreneurial way, especially in transferring the technology to the market. This strategic and holistic intermediation can reduce the distance between university and private sector and it can bring a lesson to Brazilian NIS of using intermediation in a strategic role. Previous literature points out the distance between public and private sectors in terms of innovation (Pontes, 2015) and TTOs can make the bridge for an applied and collaborative research. TTOs would not only find a partner but manage long-term collaborative research.

This section presented an analysis of main findings considering the roles of the TTOs. It was possible to integrate and synthesize the main findings and literature about intermediaries' roles in propositions and a framework describing processes in which TTOs can help collaborative projects. Next section elaborates some contributions of the research for theory and practice as well as implications for TTOs based on the British experience. 


\section{Conclusions}

This study was motivated by the growing importance of innovation intermediaries and by the inexistent knowledge in the literature of innovation placed upon the roles of TTOs throughout all the stages of collaborative $\mathrm{R} \& \mathrm{D}$ projects. Recognizing the importance of the interaction among universities and firms, TTOs are strong bridges between partners on innovation projects. Therefore, our goal in this paper was to better identify the roles of TTOs as innovation intermediaries throughout collaborative R\&D projects and suggest lessons for Brazilian TTOs based on the experience of the UK.

Watkins, Papaioannou, Mugwagwa and Kale (2015) said that the role and function of intermediaries as institutional actors in the NIS is not concretely identified. However, considering previous literature and findings from our research, we may draw some conclusions. The empirical analysis of two TTOs demonstrated the variety of their activities in collaborative projects. While both TTOs engaged in some similar activities, they differed in their portfolio of processes. Some of the activities are influenced by intermediaries, such as the mutual understanding between partners, and most of the activities are performed by the intermediary (negotiating rules for partner's participation on the project, drafting contracts, filing the intellectual property registration and commercializing the result of $R \& D$ activities).

In our study, the UK TTO had a strategic role connecting university and private sector while the Brazilian TTO was mainly helping with paperwork. We point out that the analysis in two different countries did not search for comparisons, but searched for a holistic approach of TTOs as intermediaries in different NISs. The results about TTOs' roles may depend on the country and on the project's industrial segment. Brazilian universities have human capital creation as the main activity (Rapini et al., 2015). In the UK, TTOs have been interacting with the industry for more than a century and performing mainly in patents, licensing, and spin-off creation (Siegel et al., 2007). As Hossain (2012, p. 754) affirms, "intermediary market for innovation is mostly prevailing in a few advanced countries." Therefore, from the UK case, there are a number of lessons for the development of TTOs in Brazilian universities.

First, we could suggest that universities in Brazil should offer formal training in science and technology management and market skills for TTOs' staff in order to help the productive sector to absorb and appropriate the knowledge generated at scientific sites. Second, the translator and conflict resolution role of the British TTO leads us to conclude that the intermediary would influence better results if its involvement with the inter-organizational project happens throughout the execution of R\&D activities by partners, not only in the beginning or in the end of the project, such as occurred in the Brazilian case.

The third implication regards the active search and appraisal of partners, who share the interest either on outsourcing a solution or on developing collaborative activities with the university. This was not seen on the Brazilian case. By increasing the number of actors involved in a project, it could expand the scope of knowledge involved in innovation activities.

And fourth, considering financial results for the university from the exploration of research, the active commercialisation efforts from the University of Southampton with the negotiation and definition of licensing deals may also be an example of activity for universities in a developing country such as Brazil, where science is being generated but is rarely reaching an applied usage by the industry. Expanding the suggestion to policymakers, there should be an intentional and strategic focus on creating programs to facilitate the acceleration of the commercialisation of innovation as means to increase financial results for the universities that could turn into new funds to allow more research projects, following the logic of the strategic intermediary level of the NSI as explained by Meulen and Rip (1998). The financial difficulties to innovation in developing countries could be partly overcome by private funding derived from the technology commercialisation. Further research can focus in regulatory aspects of TTOs in different countries, as this was not our focus but appeared as a barrier in the Brazilian data collection. 
Even though having provided theoretical and empirical contributions, this study is subject to limitations. The generalization of the findings, though, is restricted by the traditional limitations of qualitative studies regarding the small number of cases, which deprives statistical generalizations (Eisenhardt, 1989; Yin, 2009). The use of some techniques such as multiple sources of evidence and having a draft reviewed by key informants, as already mentioned, enhances the scientific reliability and validity of the research. Nevertheless, the contributions of the research are supported by theoretical background which grants some degree of generalization to the conclusions.

\section{Acknowledgements}

This work has received financial support by the National Council for the Improvement of Higher Education (CAPES) of Brazil.

\section{References}

Agogué, M., Yström, A., \& Le Masson, P. (2013). Rethinking the role of intermediaries as an architect of collective exploration and creation of knowledge in open innovation. International Journal of Innovation Management, 17(2), 1350007. https://doi.org/10.1142/s1363919613500072

Agogué, M., Berthet, E., Fredberg, T., Le Masson, P., Segrestin, B., Stoetzel, M., Wiener, M., \& Ystrom, A. (2017). Explicating the role of innovation intermediaries in the "unknown": A contingency approach. Journal of Strategy and Management, 10(1), 19-39. https://doi.org/10.1108/jsma-012015-0005

Agrawal, A. (2006). Engaging the inventor: Exploring licensing strategies for university inventions and the role of latent knowledge. Strategic Management Journal, 27(1), 63-79. https://doi.org/10.1002/smj.508

Alexander, A. T., \& Martin, D. P. (2013). Intermediaries for open innovation: A competence-based comparison of knowledge transfer offices practices. Technological Forecasting and Social Change, 80(1), 38-49. https://doi.org/10.1016/j.techfore.2012.07.013

Almeida, M. (2008). Innovation and entrepreneurship in Brazilian universities. International Journal of Technology Management \& Sustainable Development, $\quad 7(1), \quad 39-58$. https://doi.org/10.1386/ijtm.7.1.39_1

Bachmann, R., \& Zaheer, A. (2008). Trust in inter-organizational relations. In S. Cropper, M. Ebers, C. Huxham, \& P. Smith Ring (Eds.), The Oxford handbook of inter-organizational relations (pp. 533-554). Oxford: Oxford University Press.

Bardin, L. (1991). Análisis de contenido. Madri, España: Ediciones Akal.

Batterink, M. H., Wubben, E. F. M., Klerkx, L., \& Omta, S. W. F. (2010). Orchestrating innovation networks: The case of innovation brokers in the agri-food sector. Entrepreneurship and Regional Development, 22(1), 47-76. https://doi.org/10.1080/08985620903220512

Battistella, C., De Toni, A. F., \& Pillon, R. (2016). Inter-organisational technology/knowledge transfer: A framework from critical literature review. The Journal of Technology Transfer, 41(5), 11951234. https://doi.org/10.1007/s10961-015-9418-7

Bell, M., \& Pavitt, K. (1997). Technological accumulation and industrial growth: Contrasts between developed and developing countries. In D. Archibugy \& J. Michie (Eds.), Technology, globalisation and economic performance (pp. 83-137). Cambridge: Cambridge University Press. 
Benassi, M., \& Di Minin, A. (2009). Playing in between: Patent brokers in markets for technology. $R \& D$ Management, 39(1), 68-86. https://doi.org/10.1111/j.1467-9310.2008.00537.x

Bessant, J., \& Rush, H. (1995). Building bridges for innovation: The role of consultants in technology transfer. Research Policy, 24(1), 97-114. https://doi.org/10.1016/0048-7333(93)00751-E

Billington, C., \& Davidson, R. (2013). Leveraging open innovation using intermediary networks. Production and Operations Management, 22(6), 1464-1477. https://doi.org/10.1111/j.19375956.2012.01367.x

Bryman, A. (2001) Social research methods. Oxford: Oxford University Press.

Carayannis, E. G., Cherepovitsyn, A. Y., \& Ilinova, A. A. (2016). Technology commercialization in entrepreneurial universities: the US and Russian experience. The Journal of Technology Transfer, 41(5), 1135-1147. https://doi.org/10.1007/s10961-015-9406-y

Chesbrough, H. W. (2003). Open innovation: The new imperative for creating and profiting from technology. Boston: Harvard Business School.

Chesbrough, H. W., Vanhaverbeke, W., \& West, J. (2006). Open innovation: Researching a new paradigm. Oxford: Oxford University Press.

Creswell, J. W. (2013). Research design: Qualitative, quantitative, and mixed methods approaches. London: Sage Publications.

Dahlman, C., \& Frischtak, C. (1993). National systems supporting technical advance in industry: The Brazilian experience. In R. R. Nelson (Ed.), National innovation systems: A comparative analysis (Chap. 13, pp. 76-114). New York, Oxford: Oxford University Press.

Department for Business, Innovation \& Skills. (2012, May). First findings from the UK innovation survey 2011. Retrieved March 10, 2013, from http://webarchive.nationalarchives.gov.uk/20121205083810/http://www.bis.gov.uk/assets/bisco re/science/docs/f/12-p107-first-findings-uk-innovation-survey-2011.pdf

Deschamps, I., Macedo, M. G., \& Eve-Levesque, C. (2013). University-SME collaboration and open innovation: Intellectual-property management tools and the roles of intermediaries. Technology Innovation Management Review, 3(3), 33-21. Retrieved from https://timreview.ca/sites/default/files/article_PDF/Deschamps_et_al_TIMReview_March2013. pdf

Dodgson, M., Gann, D., \& Salter, A. (2006). The role of technology in the shift towards open innovation: The case of Procter \& Gamble. $R \& D$ Management, 36(3), 333-346. https://doi.org/10.1111/j.1467-9310.2006.00429.x

Dyer, J. H., \& Nobeoka, K. (2000). Creating and managing a high-performance knowledge-sharing network: The Toyota case. Strategic Management Journal, 21(3), 345-367. https://doi.org/10.1002/(sici)1097-0266(200003)21:3\%3C345::aid-smj96\%3E3.0.co;2-n

Eisenhardt, K. M. (1989). Building theories from case-study research. Academy of Management Review, 14(4), 532-550. https://doi.org/10.5465/amr.1989.4308385

Eisenhardt, K. M., \& Graebner, M. E. (2007). Theory building from cases: Opportunities and challenges. Academy of Management Journal, 50(1), 25-32. https://doi.org/10.5465/amj.2007.24160888

Etzkowitz, H., Mello, J. M. C. de, \& Almeida, M. (2005). Towards "meta-innovation" in Brazil: The evolution of the incubator and the emergence of a triple helix. Research Policy, 34(4), 411-424. https://doi.org/10.1016/j.respol.2005.01.011 
Folha de S. Paulo. (n.d.). Ranking Universitário Folha 2013 - Ranking por inovação. Retrieved July 22, 2016, from http://ruf.folha.uol.com.br/2013/rankinguniversitariofolha/rankingporinovacao/

Freeman, C. (1995). The 'national system of innovation' in historical perspective. Cambridge Journal of Economics, 19(1), 5-24. https://doi.org/10.1093/oxfordjournals.cje.a035309

Freeman, C. (2002). Continental, national and sub-national innovation systems - Complementarity and economic growth. Research Policy, 31(2), 191-211. https://doi.org/10.1016/S00487333(01)00136-6

Gassmann, O., Daiber, M., \& Enkel, E. (2011). The role of intermediaries in cross-industry innovation processes. $R \& D \quad$ Management, $\quad 41(5), \quad 457-469 . \quad$ https://doi.org/10.1111/j.14679310.2011.00651.x

Gianiodis, P. T., Ellis, S. C., \& Secchi, E. (2010). Advancing a typology of open innovation. International Journal of Innovation Management, 14(4), 531-572. https://doi.org/10.1142/s1363919610002775

Guerrero, M., Urbano, D., \& Herrera, F. (2017). Innovation practices in emerging economies: Do university partnerships matter?. The Journal of Technology Transfer, 1-32. https://doi.org/10.1007/s10961-017-9578-8

Hacievliyagil, N. K., Maisonneuve, Y. E., Auger, J., \& Hartmann, D. (2007). The positions of virtual knowledge brokers in the core process of open innovation. The International Journal of Technology, Knowledge and Society, 3(5), 47-59. https://doi.org/10.18848/18323669/CGP/v03i05/55779

Hossain, M. (2012). Performance and potential of open innovation intermediaries. Procedia - Social and Behavioral Sciences, 58, 754-764. https://doi.org/10.1016/j.sbspro.2012.09.1053

Howells, J. (2006). Intermediation and the role of intermediaries in innovation. Research Policy, 35(5), 715-728. https://doi.org/10.1016/j.respol.2006.03.005

Huyghe, A., Knockaert, M., Piva, E., \& Wright, M. (2016). Are researchers deliberately bypassing the technology transfer office? An analysis of TTO awareness. Small Business Economics, 47(3), 589-607. https://doi.org/10.1007/s11187-016-9757-2

Instituto Brasileiro de Geografia e Estatística. (2013). Pesquisa de Inovação - PINTEC 2011. Retrieved July 10, 2013, from https://biblioteca.ibge.gov.br/visualizacao/livros/liv81830.pdf

Jensen, P. H., Palangkaraya, A., \& Webster, E. (2015). Trust and the market for technology. Research Policy, 44(2), 340-356. https://doi.org/10.1016/j.respol.2014.10.001

Kim, Y. K., \& Lee, K. (2015). Different impacts of scientific and technological knowledge on economic growth: Contrasting science and technology policy in East Asia and Latin America. Asian Economic Policy Review, 10(1), 43-66. https://doi.org/10.1111/aepr.12081

Kivimaa, P. (2014). Government-affiliated intermediary organisations as actors in system-level transitions. Research Policy, 43(8), 1370-1380. https://doi.org/10.1016/j.respol.2014.02.007

Klerkx, L., Hall, A., \& Leeuwis, C. (2009). Strengthening agricultural innovation capacity: Are innovation brokers the answer?. International Journal of Agricultural Resources, Governance and Ecology, 8(5/6), 409-438. https://doi.org/10.1504/ijarge.2009.032643

Kotabe, M., \& Swan, K. S. (1995). The role of strategic alliances in high-technology new product development. Strategic Management Journal, 16(8), 621-636. http://dx.doi.org/10.1002/smj.4250160804 
Lee, H., \& Kang, P. (2017). Identifying core topics in technology and innovation management studies: A topic model approach. The Journal of Technology Transfer, 1-27. https://doi.org/10.1007/s10961-017-9561-4

Li, J., \& Kozhikode, R. K. (2009). Developing new innovation models: Shifts in the innovation landscapes in emerging economies and implications for global R\&D management. Journal of International Management, 15(3), 328-339. https://doi.org/10.1016/j.intman.2008.12.005

Lichtenthaler, U. (2013). The collaboration of innovation intermediaries and manufacturing firms in the markets for technology. Journal of Product Innovation Management, 30, 1-17. https://doi.org/10.1111/jpim.12068

Lundvall, B. (1992). National systems of innovation: An analytical framework. London: Pinter.

Mazzoleni, R., \& Nelson, R. (2007). Public research institutions and economic catch-up. Research Policy, 36(10), 1512-1528. https://doi.org/10.1016/j.respol.2007.06.007

Munari, F., Rasmussen, E., Toschi, L., \& Villani, E. (2016). Determinants of the university technology transfer policy-mix: A cross-national analysis of gap-funding instruments. The Journal of Technology Transfer, 41(6), 1377-1405. https://doi.org/10.1007/s10961-015-9448-1

Natalicchio, A., Petruzzelli, A. M., \& Garavelli, A. C. (2014). A literature review on markets for ideas: Emerging characteristics and unanswered questions. Technovation, 34(2), 65-76. https://doi.org/10.1016/j.technovation.2013.11.005

Nelson, R. R., \& Rosenberg, N. (1993). Technical innovation and national systems. In R. R. Nelson (Ed.), National innovation systems: A comparative analysis (pp. 1-18). Oxford University Press, Oxford.

Organisation for Economic Co-operation and Development. (2005). Oslo manual: Guidelines for collecting and interpreting technological innovation data. Paris: OECD Publishing.

Okamuro, H. (2007). Determinants of successful R\&D cooperation in Japanese small businesses: The impact of organizational and contractual characteristics. Research Policy, 36(10), 1529-1544. https://doi.org/10.1016/j.respol.2006.12.008

Pittaway, L., Robertson, M., Munir, K., Denyer, D., \& Neely, A. (2004). Networking and innovation: A systematic review of the evidence. International Journal of Management Reviews, 5/6(3/4), 137168. https://doi.org/10.1111/j.1460-8545.2004.00101.x

Polzin, F., Flotow, P., von, \& Klerkx, L. (2016). Addressing barriers to eco-innovation: Exploring the finance mobilisation functions of institutional innovation intermediaries. Technological Forecasting and Social Change, 103, 34-46. https://doi.org/10.1016/j.techfore.2015.10.001

Pontes, P. (2015). Brazilian scientific production vs. innovation and technology. Brazilian Journal of Otorhinolaryngology, 81(4), 343-344. https://doi.org/10.1016/j.bjorl.2015.05.001

Provan, K. G., \& Kenis, P. (2008). Modes of network governance: Structure, management, and effectiveness. Journal of Public Administration Research and Theory, 18(2), 229-252. https://doi.org/10.1093/jopart/mum015

QS. (2017). QS world university rankings 2018. Retrieved August 9, 2017, from https://www.topuniversities.com/university-rankings/world-university-rankings/2018

Rapini, M. S., Chiarini, T., \& Bittencourt, P. F. (2015). University-firm interactions in Brazil: Beyond human resources and training missions. Industry \& Higher Education, 29(2), 111-127. https://doi.org/10.5367/ihe.2015.0245 
Radosevic, S. (2011). Science-industry links in Central and Eastern Europe and the Commonwealth of Independent States: Conventional policy wisdom facing reality. Science and Public Policy, 38(5), 365-378. https://doi.org/10.3152/030234211x12924093660435

Riege, A. M. (2003). Validity and reliability tests in case study research: A literature review with "handson" applications for each research phase. Qualitative Market Research: An International Journal, 6(2), 75-86. https://doi.org/10.1108/13522750310470055

Santoro, M. D. (2000). Success breeds success: The linkage between relationship intensity and tangible outcomes in industry-university collaborative ventures. The Journal of High Technology Management Research, 11(2), 255-273. https://doi.org/10.1016/S1047-8310(00)00032-8

Scandura, A. (2016). University-industry collaboration and firms' R\&D effort. Research Policy, 45(9), 1907-1922. https://doi.org/10.1016/j.respol.2016.06.009

Siegel, D. S., Veugelers, R., \& Wright, M. (2007). Technology transfer offices and commercialization of university intellectual property: Performance and policy implications. Oxford Review of Economic Policy, 23(4), 640-660. https://doi.org/10.1093/oxrep/grm036

Suzigan, W., \& Albuquerque, E. M. (2011). The underestimated role of universities for the Brazilian system of innovation. Revista de Economia Política, 31(1), 3-30. http://dx.doi.org/10.1590/S0101-31572011000100001

Trippl, M., Sinozic, T., \& Smith, H. L. (2015). The role of universities in regional development: Conceptual models and policy institutions in the UK, Sweden and Austria. European Planning Studies, 23(9), 1722-1740. http://dx.doi.org/10.1080/09654313.2015.1052782

University of Southampton. (n.d.). Commercialising research. Retrieved from 15 March, 2017, from https://www.southampton.ac.uk/research/commercialising.page

University of Southampton. (2013, January 15). Royal Society selects Southampton invention for Royal $\begin{array}{lllll}\text { visitor. } & \text { Retrieved } 22 \text { July, 2016, from }\end{array}$ https://www.southampton.ac.uk/engineering/news/2013/01/15_royal_visit.page

Meulen, B. van der, \& Rip, A. (1998). Mediation in the Dutch science system. Research Policy, 27(8), 757-769. https://doi.org/10.1016/S0048-7333(98)00088-2

Van de Ven, A. H. (2007). Engaged scholarship: A guide for organizational and social research. Oxford, UK: Oxford University Press.

Villani, E., Rasmussen, E., \& Grimaldi, R. (2017). How intermediary organizations facilitate universityindustry technology transfer: A proximity approach. Technological Forecasting \& Social Change, 114, 86-102. https://doi.org/10.1016/j.techfore.2016.06.004

Watkins, A., Papaioannou, T., Mugwagwa, J., \& Kale, D. (2015). National innovation systems and the intermediary role of industry associations in building institutional capacities for innovation in developing countries: A critical review of the literature. Research Policy, 44(8), 1407-1418. https://doi.org/10.1016/j.respol.2015.05.004

Winch, G. M., \& Courtney, R. (2007). The organization of innovation brokers: An international review. Technology Analysis \& Strategic Management, 19(6), 747-763. http://dx.doi.org/10.1080/09537320701711223

Yin, R. K. (2009). Case study research: Design and methods (4th ed.). Los Angeles: Sage Publications. 


\section{Authors' Profiles}

\section{Elisa Thomas}

University of Stavanger, UiS Business School, P.O.Box 8600 Forus, N-4036, Stavanger, Rogaland, Norway. E-mail address: elisa.thomas@uis.no.http://orcid.org/0000-0001-6099-7357

Luciana Marques Vieira

Av. 9 de Julho, 2029, Bela Vista, 01313-902, São Paulo, SP, Brazil. E-mail address: luciana.vieira@ fgv.br

Alsones Balestrin

Av. Unisinos, 950, 93020-190, São Leopoldo, RS, Brazil. E-mail address: abalestrin@ unisinos.br 